\title{
Higher Education law revised
}

THE Polish Higher Education Act of 1982, which embodies a watered down version of the reforms of the Solidarity period, is now up for revision. Last month, a "public debate" was launched on proposed amendments to the act. Discussion is somewhat hampered, however, because no provisional draft of the proposed changes has been officially published. But reports in the underground press claim that the Ministry of Science, Higher Education and Technology wishes to deprive the universities of virtually all the autonomy won in 1980-81 and embodied in the 1982 act.

The minister himself, Dr Benon Miskiewicz, in an interview with the official Polish news agency PAP at the beginning of the present academic year, made barelyveiled threats that the law would be revised if the self-government bodies in higher education continued to exercise their autonomy. Within a few weeks, an alleged draft of the proposed changes began to circulate in academic circles, claiming to be a "confidential" document leaked to Solidarity by a source within the Ministry of Science, Higher Education and Technology. Miskiewicz repudiated the document, claiming that it was simply a "provocation" engineered by "antisocialist forces". Nevertheless, in a meeting with the Main Council for Higher Education, he outlined a scheme of tentative changes which one participant in the meeting described as "the same only less detailed" than the underground draft.

According to the draft, the proposed changes include:

- Replacement of the open elections for university rectors by a choice between two candidates nominated by the minister; the successful candidate would then nominate the various deans who are also, at present, elected.

Depriving the university senates and faculty councils ("collegial bodies") of various rights which would then be vested in the selected nominees.

- Removing from the collegial bodies the representatives of students, junior academic staff and auxiliary staff (such as librarians), leaving only senior academics and party and military representatives.

- Empowering the minister to suspend or disband any collegial body, and to dismiss university staff and expel students, if he deems their activities "contrary to the interests of society".

- Reorganizing the students' selfgovernment bodies, described as an obstacle to "comprehensive socialist development" on the basis of the partylinked youth organizations, thereby bringing all matters of student welfare and social activity under party control.

Not surprisingly, former Solidarity activists in the universities and members of the pro-Solidarity Independent Students'
Association (NZS) are opposed to the changes. Equally inevitably, the student "self-government committees" want to put up a fight, although the 1982 act forbids any formal links between the selfgovernment committees of different universities and colleges, giving the minister an additional weapon against them.

More significant is the opposition shown by the Main Council for Higher Education. This is also an innovation of the Solidarity period, and consists of one representative of every higher education institution in Poland (except the Catholic University of Lublin). Many of the delegates to the Main Council are, however, Party members, elected because the universities feel that they might prove effective in putting over the university viewpoint to state and Party authorities without unnecessary hassle. The principal objection of the Main Council is that, even if the changes are necessary, they are premature. The existing law, it says, should be allowed to run for at least another thre years, until the expiry of the term of office of the rectors elected under the law. Chopping and changing so quickly can only destabilize the universities.

Individual academics have spoken out strongly in favour of academic autonomy and the present structure of student "selfgovernment committees"; they include Dr Jozef Gierowski, of the Jagiellonian University of Krakow and Dr Grzegorz Bialkowski of Warsaw who was elected in November in place of $\mathrm{Dr}$ Klemens Szaniawski, whose election in May was vetoed by Minister Miskiewicz. Some of their statements and press interviews were made before the official launching of the debate and make no direct reference to changing the act. Nevertheless, their tacit opposition to the proposals is clear. So far, the only group reported to have come out in favour of the change is a "young scientist" conference held earlier this month under the auspices of the official "Association of Polish Students"'. Even they, however, urged the active participation in academic decision-making by students, junior lecturers and auxiliary staff.

Vera Rich

\section{Research animals}

\section{Tiger salamanders perpetuated}

\section{Washington}

AN ad hoc international campaign by retinal physiologists seems to have secured at least a temporary reprieve for the world's only source of captive-bred tiger salamanders. Retinal cells from the tiger salamander, Ambystoma tigrinum, are widely used in vision research, and have the potential to become "a classic preparation", in the words of one researcher. The problem is that only one man, 71-year-old Carl Lowrance, knows how to rear in quantity the giant specimens (up to 12 inches long) preferred by physiologists, and his breeding ponds have suffered heavy pollution by sewage and animal slaughter effluent from a local meat-packing plant.

Lowrance is an energetic self-taught natural biologist in the nineteenth century tradition living in Tulsa, Oklahoma. Since inventing the sonar fish locator earlier in his career, he has spent the past 15 years perfecting techniques for culturing salamanders, primarily for use as fish bait. Lowrance says 30 variables must be controlled to rear the animals successfully, from $p \mathrm{H}$ and oxygen content of the water to presence of predators. He had been producing half a million salamanders a year before the pollution killed 250,000 animals and made his ponds largely unusable. But Lowrance is unwilling now to go into debt to finance a business expansion, and has had difficulty finding a farmer willing to pay a consulting fee to learn his techniques. "They just copy what they see", he says. "They don't really study and so they don't understand."

Retinal physiologists were alerted to the threat hanging over their favourite research animal by Dr Ed Pugh of the University of Pennsylvania. Besides the remarkable size of Lowrance's specimens, their value is that they come from a relatively homogeneous breeding population and have known histories. The retinal cells are large (see p.529), and, unlike those of other species, can be maintained in culture. Several Papers based on the tiger salamander preparation are published in this issue of Nature (pp. 582 and 585).

Eric Schwarz of the University of Chicago has written that research on phototransduction is "critically dependent" on supplies of tiger salamanders. Armed with this and other letters of support from prominent physiologists throughout the world, Pugh has persuaded the National Science Foundation and the National Institutes of Health to provide $\$ 26,000$ and $\$ 21,000$ respectively to set up temporary breeding ponds over the next couple of years or so. The tiger salamander is an endangered species in some states.

Lowrance is now helping to transfer salamanders to the new ponds and is grateful for the scientists' conservation efforts: he takes an active interest in the research supported by his animals. $\mathrm{He}$ is now negotiating with several fish breeders who seem interested in learning his methods, and may soon be teaching them. In the longer term, there are some hopes among researchers of setting up a foundation to preserve salamanders - but plans are still a long way off, and it is by no means certain that Carl Lowrance's skills will be preserved.
Tim Beardsley 